\title{
Erratum to Functional significance of intramandibular bending in Poeciliid fishes
}

\author{
Alice Gibb • Lara A. Ferry-Graham • \\ L. Patricia Hernandez • Rebecca Romasco • \\ Jessica Blanton
}

Published online: 17 October 2008

(C) Springer Science + Business Media B.V. 2008

\section{Erratum to: Environ Biol Fish \\ DOI 10.1007/s10641-008-9369-z}

Unfortunately, the author name Rebecca Romansco was mispelled and should appear as Rebecca Romasco.

The online version of the original article can be found at http:// dx.doi.org/10.1007/s10641-008-9369-z.

A. Gibb $(\bowtie) \cdot$ R. Romasco $\cdot$ J. Blanton Department of Biological Sciences, Northern Arizona University, Flagstaff, AZ 86011-5640, USA e-mail: Alice.Gibb@nau.edu

L. A. Ferry-Graham

Moss Landing Marine Laboratories, California State University,

8272 Moss Landing Rd,

Moss Landing, CA 95039, USA

L. P. Hernandez

Department of Biological Sciences, The George Washington University, Washington, DC 20052, USA 